\title{
In vitro and In silico Models to Study SARS-CoV-2 Infection: Integrating Experimental and Computational Tools to Mimic "COVID-19 Cardiomyocyte"
}

\author{
Rafael Dariolli*, Chiara Campana, Amy Gutierrez and Eric A. Sobie \\ Department of Pharmacological Sciences, Icahn School of Medicine at Mount Sinai, New York, NY, United States
}

The rapid dissemination of SARS-CoV-2 has made COVID-19 a tremendous social, economic, and health burden. Despite the efforts to understand the virus and treat the disease, many questions remain unanswered about COVID-19 mechanisms of infection and progression. Severe Acute Respiratory Syndrome (SARS) infection can affect several organs in the body including the heart, which can result in thromboembolism,

OPEN ACCESS

Edited by:

Deborah Schechtman,

University of São Paulo, Brazil

Reviewed by:

Kevin E. Healy,

University of California, Berkeley,

United States

Aslak Tveito,

Simula Research Laboratory, Norway

${ }^{*}$ Correspondence: Rafael Dariolli

rafael.dariolli@mssm.edu

Specialty section:

This article was submitted to

Integrative Physiology,

a section of the journal

Frontiers in Physiology

Received: 30 October 2020 Accepted: 25 January 2021

Published: 17 February 2021

Citation:

Dariolli $R$, Campana $C$ Gutierrez A and Sobie EA (2021) In vitro and In silico Models to Study SARS-CoV-2 Infection: Integrating Experimental and Computational

Tools to Mimic "COVID-19

Cardiomyocyte".

Front. Physiol. 12:624185. doi: 10.3389/fphys.2021.624185 myocardial injury, acute coronary syndromes, and arrhythmias. Numerous cardiac adverse events, from cardiomyocyte death to secondary effects caused by exaggerated immunological response against the virus, have been clinically reported. In addition to the disease itself, repurposing of treatments by using "off label" drugs can also contribute to cardiotoxicity. Over the past several decades, animal models and more recently, stem cell-derived cardiomyocytes have been proposed for studying diseases and testing treatments in vitro. In addition, mechanistic in silico models have been widely used for disease and drug studies. In these models, several characteristics such as gender, electrolyte imbalance, and comorbidities can be implemented to study pathophysiology of cardiac diseases and to predict cardiotoxicity of drug treatments. In this Mini Review, we (1) present the state of the art of in vitro and in silico cardiomyocyte modeling currently in use to study COVID-19, (2) review in vitro and in silico models that can be adopted to mimic the effects of SARS-CoV-2 infection on cardiac function, and (3) provide a perspective on how to combine some of these models to mimic "COVID-19 cardiomyocytes environment."

Keywords: COVID-19, SARS-CoV-2, cardiomyocytes, hiPSC-CMs, modeling, pluripotent stem cells

\section{INTRODUCTION}

Since the first reported case in Wuhan, China on December 31st, 2019, the Severe Acute Respiratory Syndrome coronavirus 2 (SARS-CoV-2) has precipitated the coronavirus disease 2019 (COVID19) pandemic, a global socio-economic and health burden (Bialek et al., 2020; Guan et al., 2020). As of January 08th, 2021, the total number of confirmed cases reported is approximately 86 million with more than 1.8 million deaths registered (WHO, 2020). The disease can affect most of the population with factors such as age, gender, race, socioeconomic status affecting prognosis (Gebhard et al., 2020; Golestaneh et al., 2020; Sharma G. et al., 2020; Zhou F. et al., 2020). 
Additionally, pre-existing cardiovascular diseases (CVDs) such as hypertension, diabetes, and heart failure are prevalent in cohorts of patients with the most serious forms of COVID-19 (Goyal et al., 2020; Grasselli et al., 2020; Guan et al., 2020; Huang C. et al., 2020; Wu and McGoogan, 2020).

At the cellular level, SARS-CoV-2 infects its target by engaging with the angiotensin-converting enzyme 2 (ACE2) receptor, followed by cleavage of the viral spike (S) protein by the host serine protease TMPRSS2. Once in the cytoplasm, the viral RNA is replicated and released via exocytosis causing cellular damage (Hoffmann et al., 2020). In fact, human RNA sequencing has shown that the expression of both ACE2 and TMPRSS2 can be found in multiple organs (Chen et al., 2020), suggesting that SARS-CoV-2 might infect several target tissues.

Similar to the viruses responsible for the 2003 SARS outbreak and the 2012 MERS outbreak (Yu et al., 2006; Alhogbani, 2016), SARS-CoV-2 can trigger cardiovascular illnesses such as thromboembolism, myocardial injury, acute coronary syndromes, and arrhythmias (Clerkin et al., 2020; Madjid et al., 2020; Zheng et al., 2020). The heart is composed of many cell types including cardiomyocytes, endothelial cells, pericytes, epithelial cells, fibroblasts, smooth muscle cells, and immune cells (Pinto et al., 2016; Zhou and Pu, 2016; Chen et al., 2020) with all cell types contributing in some way to the overall cardiac function (Borg et al., 1996). Given the central role of cardiomyocytes in force generation and the minimal regenerative capacity of these cells (Cohn et al., 2000), avoiding cardiomyocyte damage and loss is of paramount importance to survival.

In the context of COVID-19, patients with poor prognosis who require hospitalization tend to exhibit a high prevalence of CVDs before viral infection. To understand the cardiovascular manifestations of COVID-19 and its treatments, experimental and mathematical cardiomyocyte models are likely to be of value. In this Mini Review, we: (1) present the state of the art of in vitro and in silico models of cardiomyocytes currently in use to study COVID-19, (2) review in vitro and in silico models that can be adopted to mimic the effects of SARS-CoV-2 infection on cardiac function, and (3) propose a perspective on how to create robust models that resemble a "COVID-19 cardiomyocyte environment" though the combination of in vitro and in silico strategies.

\section{MODELING THE "COVID-19 CARDIOMYOCYTE" IN VITRO}

In some of the first autopsies of deceased COVID-19 patients, electron microscopy identified viral particles compatible with the Coronaviridae family in multiple cardiac cell types, including cardiomyocytes, endothelial cells, macrophages, neutrophils, and fibroblasts (Dolhnikoff et al., 2020; Fox et al., 2020a,b; Lax et al., 2020; Lindner et al., 2020). Despite this preliminary evidence, the mechanism of direct infection of human adult cardiomyocytes is still not completely elucidated.

A recent single-cell sequencing of adult hearts demonstrated that expression of ACE2 receptors is higher in pericytes than in cardiomyocytes (Chen et al., 2020). Additionally, neither pericytes nor cardiomyocytes seem to significantly express the protease TMPRSS2 (Litviňuková et al., 2020), strongly suggesting that, if SARS-CoV-2 does in fact enter cardiomyocytes, it may do so through a pathway other than ACE2/TMPRSS2 (PérezBermejo et al., 2020; Yang and Shen, 2020). Further, the high expression of ACE2 receptors in endothelial cells suggests that they represent a likely source of SARS-CoV-2 infection. In fact, the infection of endothelial cells by SARS-CoV-2 results in blood vessel inflammation (endotheliitis) in multiple organs, including the heart (Varga et al., 2020).

In this context, the use of in vitro models has been proposed in an effort to overcome the limitations related to the use of human tissues post-mortem (Yang et al., 2020). Human induced pluripotent stem-cell derived cardiomyocytes (hiPSCCMs) can be directly infected by SARS-CoV-2 (Bojkova et al., 2020; Marchiano et al., 2020; Sharma A. et al., 2020; Yang et al., 2020). These infected cells display impairment of their spontaneous beating behavior (Bojkova et al., 2020; Marchiano et al., 2020; Sharma A. et al., 2020). Additionally, an excessive increase of caspase-3 cleavage, which drives cells to an apoptotic program, has been reported in these cells (Bojkova et al., 2020; Sharma A. et al., 2020).

Recent reports have suggested that hiPSC-CMs are infected via an alternative route involving the ACE2 receptor and cathepsindependent endolysosomes (Bojkova et al., 2020; Marchiano et al., 2020; Pérez-Bermejo et al., 2020), rather than through TMPRSS2 protease cleavage (Hoffmann et al., 2020). In fact, hiPSC-CMs display low expression of TMPRSS2 while cathepsins-L and $\mathrm{B}$, cysteine proteases which are also able to mediate priming of the viral S-protein (Hoffmann et al., 2020), are highly expressed in these cells (Bojkova et al., 2020). Furthermore, the block of cathepsins by chemical inhibition results in significant reduction of viral particles in hiPSC-CMs (Bojkova et al., 2020; PérezBermejo et al., 2020).

In addition, SARS-CoV-2 exposure induces significant transcriptional changes resulting in the disruption of the contractile apparatus of hiPSC-CMs (Pérez-Bermejo et al., 2020). These cytopathic effects progressively affect hiPSC-CM electrophysiological and contractile properties as recently demonstrated. Microelectrode array measurements of hiPSCCMs infected with SARS-CoV-2 documented a significant increase in their field potential duration (Marchiano et al., 2020), an in vitro surrogate for arrhythmogenicity. Similarly, infected three-dimensional engineered heart tissues displayed progressive impairment of contractility suggesting a disruption of the contractile apparatus following infection with SARS-CoV-2, which may contribute to whole-organ dysfunction (Huang L. et al., 2020; Marchiano et al., 2020).

Despite the exciting results describing the direct infection of cardiomyocytes by SARS-CoV-2, increasing clinical evidence points toward the indirect effects of the infection accounting for the most prevalent and severe cases that exhibit cardiac repercussions (Clerkin et al., 2020; Zheng et al., 2020). The field currently lacks robust models that can clarify these aspects of COVID-19 at the cardiomyocyte level.

Rising evidence shows that COVID-19 patients with worse prognosis present cardiac damage that correlates with the concentration of pro-inflammatory molecules (Akhmerov and Marbán, 2020; Ruan et al., 2020; Zhou F. et al., 2020). Indeed, severe symptoms, mainly related to the 
hyperinflammation and deficit of oxygenation, have been described in the most aggressive cases (Iannaccone et al., 2020; Lax et al., 2020). The inability to promptly defeat a viral infection can elicit a cytokine storm, in which pro-inflammatory molecules including Interleukin-1 $\beta$ (IL-1 $\beta$ ), Interleukin-6 (IL-6), and Tumor necrosis factor (TNF- $\alpha$ ) are released in pathogenic concentrations causing systemic hyperinflammation (Iannaccone et al., 2020).

Pro-inflammatory molecules can directly cause adverse consequences in cardiomyocytes including arrhythmias (Long, 2001; El Khoury et al., 2014; Aromolaran et al., 2018; Keck et al., 2019), cellular hypertrophy (Long, 2001; Carreño et al., 2006; Smeets et al., 2008), and cell death (Wang et al., 2016). Elevated levels of IL-1 $\beta$ can trigger cardiac arrhythmias through the impairment of expression of proteins that control calcium handling, ultimately affecting cardiomyocyte's contraction (McTiernan et al., 1997; El Khoury et al., 2014). Similarly, neonatal cardiomyocytes (NCs) exposed to IL-6 in culture display augmentation of cell size suggesting cellular hypertrophy (Hirota et al., 1995). Interestingly, NCs co-cultured with fibroblasts overexpressing IL-6 are driven to apoptosis (Wang et al., 2016). Furthermore, IL-6 converts cardiac fibroblasts into myofibroblasts which produce collagen contributing to the formation of fibrosis (Wang et al., 2016). Pathological levels of IL- 6 cause down-regulation of hERG channel (ethera-go-go-related gene) expression, resulting in increased risk of action potential duration (APD) prolongation and arrhythmias (Aromolaran et al., 2018).

TNF- $\alpha$ is another pro-inflammatory molecule that triggers cardiac arrythmias and induces cardiomyocytes' hypertrophy and death (Nakamura et al., 1998; Carreño et al., 2006; Shen et al., 2018). Rat NCs treated with TNF- $\alpha$ exhibit abnormal size (Nakamura et al., 1998). Further, pathological levels of TNF- $\alpha$ can enhance mitochondrial fragmentation, promoting cell death (Shen et al., 2018), and a slow and sustained increase in hypertrophic markers through the NF-K $\beta$ pathway (Smeets et al., 2008).

The cytokine storm caused by SARS-CoV-2 triggers an acute respiratory distress syndrome (ARDS) resulting in severe outcomes such as oxygen deprivation (hypoxia) and electrolyte disturbance (e.g., hypokalemia), factors that cause cardiomyocyte distress (Bhatia et al., 2012; Coperchini et al., 2020; Xu et al., 2020). Moreover, it appears that this hypoxia may induce release of additional cytokines, potentially leading to further myocyte dysfunction. In isolated rat NCs subjected to hypoxia $\left(5 \% \mathrm{O}_{2}\right)$, production and release of IL- 6 are enhanced (Yamauchi-Takihara et al., 1995; Wang et al., 2016). In addition, conditioned media from rat NCs cultivated at $1 \% \mathrm{O}_{2}$ exhibit higher levels of TNF$\alpha$, IL- $1 \beta$, IL- 6 , and transforming growth factor beta (TGF- $\beta$ ) compared to cells cultivated in normoxia (Shi et al., 2017).

Electrolyte imbalance and fever are two other typical conditions implicated in COVID-19 patients. Several models of hypokalemia and hyperthermia have indicated that slight changes in the cellular environment can dramatically impair cardiomyocytes' stability (El-Battrawy et al., 2016; Weiss et al., 2017; Tazmini et al., 2020). Hypokalemia is a systemic decrease in the concentration of $\mathrm{K}^{+}$ions that can produce $\mathrm{APD}$ prolongation and arrhythmias in cardiomyocytes (Weiss et al., 2017), including hiPSC-CMs (Kuusela et al., 2017). In addition, arrhythmias associated with hyperthermia have also been reported in both healthy and ill individuals (Saura et al., 2002; Pasquié et al., 2004; Burrell et al., 2007), and cellular studies have reported reductions in important cardiac ion channels caused by hyperthermia (El-Battrawy et al., 2016).

Taken together, the previous reports provide substantial information on how to model several outcomes that account for the cardiac deterioration observed in many COVID-19 patients. Studies that use patient-derived hiPSC-CMs carrying inherited diseases can also be found in the literature (Granéli et al., 2019; Hoes et al., 2019; Jimenez-Tellez and Greenway, 2019). Several of these models can be adopted to evaluate additive effects of COVID-19 and pre-existing comorbidities such as heart failure, cardiomyopathies, diabetes. The most representative in vitro models that mimic COVID-19 outcomes, as well as some of the significant hiPSC lines derived from patients with pre-existing comorbidities are described in Table $\mathbf{1 .}$

\section{MODELING THE "COVID-19 CARDIOMYOCYTE" IN SILICO}

Besides the use of in vitro strategies, many authors have been reporting in silico models to study COVID-19. Most of them are concerned with predictions of mortality and risk factors (Scheiner et al., 2020; Wicik et al., 2020; Yadaw et al., 2020), disease infection and spread (Ivorra et al., 2020; Zeb et al., 2020), and drug-target interactions (Ciliberto and Cardone, 2020; Iqbal Choudhary and Shaikh, 2020; Muthuramalingam et al., 2020; Zhou Y. et al., 2020). Regarding the cardiac repercussions of COVID-19 and its potential treatments, mechanistic approaches based on dynamical models have been proposed to predict effectiveness of treatments (Iqbal Choudhary and Shaikh, 2020; Peterson, 2020), and to measure the toxicity of repurposed drugs (Sutanto and Heijman, 2020; Varshneya et al., 2020).

Notably, several drugs currently under testing have been previously reported to cause toxicity (Chary et al., 2020; Saleh et al., 2020; Smith et al., 2020; Zhang et al., 2020). Particular attention needs to be paid to drugs that can substantially increase arrhythmia risk or increase the risk of heart failure (Michaud et al., 2020), as addressed in a few recent studies. For example, Sutanto and Heijman used a canine ventricular cardiomyocyte model to simulate action potentials (APs) of cardiomyocytes treated with chloroquine (CQ) and azithromycin (AZM). The authors demonstrated that $\beta$-adrenergic stimulation is protective against CQ- and AZM-induced proarrhythmia by preventing APD prolongation and afterdepolarizations (Sutanto and Heijman, 2020). Meanwhile, our group has combined pharmacokinetics (PK) and electrophysiology modeling of human ventricular cardiomyocytes to predict the risk of potential cardiac adverse events caused by CQ, AZM, lopinavir (LP), and ritonavir (RT). Our simulations showed treatment with clinically relevant doses of $\mathrm{CQ} / \mathrm{AZM}$ was more dangerous than treatment with LP/RT, and that females with pre-existing heart failure were at the highest risk of developing ventricular arrhythmia 
TABLE 1 | In vitro models to be used to mimic "COVID-19 cardiomyocytes."

\begin{tabular}{|c|c|c|c|c|c|}
\hline Outcome & Stimuli & Treatment & Specie & Cell type & References \\
\hline \multirow[t]{8}{*}{$\begin{array}{l}\text { Inflammation/ } \\
\text { Hypertrophy }\end{array}$} & $\| \mathrm{L}-1 \beta$ & $\begin{array}{l}1 \mathrm{ng} / \mathrm{mL}, 12-16 \mathrm{~h} \text { (adult cells) } \\
\text { and } 30 \mathrm{pg} / \mathrm{mL} 24-32 \mathrm{~h}\end{array}$ & mouse & $\begin{array}{l}\text { neonatal ventricular } \\
\text { myocytes and adult } \\
\text { ventricular myocytes }\end{array}$ & El Khoury et al., 2014 \\
\hline & TNF- $\alpha$ & $\begin{array}{l}1 \mathrm{ng} / \mathrm{mL}, 12-16 \mathrm{~h} \text { and } \\
30 \mathrm{pg} / \mathrm{mL} 24-32 \mathrm{~h}\end{array}$ & & & \\
\hline & TNF- $\alpha$ & $50 \mathrm{ng} / \mathrm{mL}, 2,12,24$, and $48 \mathrm{~h}$ & rat & Neonatal cardiomyocytes & Smeets et al., 2008 \\
\hline & $\mathrm{TNF}-\alpha$ & $\begin{array}{l}\text { 1, } 10 \text {, and } 100 \mathrm{ng} / \mathrm{mL} \\
\text { (centered in } 10 \mathrm{ng} / \mathrm{mL} \text { ), from } 1 \\
\text { hour to } 3 \text { days. }\end{array}$ & rat & Neonatal cardiomyocytes & Nakamura et al., 1998 \\
\hline & $\mathrm{TNF}-\alpha$ & 5,10, and $20 \mathrm{ng} / \mathrm{mL}, 6$ or $48 \mathrm{~h}$ & rat & H9C2 rat cardiomyocytes & Shen et al., 2018 \\
\hline & IL-6 & 5,10 , and $20 \mathrm{ng} / \mathrm{mL}, 6$ or $48 \mathrm{~h}$ & & & \\
\hline & IL-6 & $2 \mu \mathrm{g} / \mathrm{mL}$ for $72 \mathrm{~h}$ & mouse & neonatal cardiomyocytes & Hirota et al., 1995 \\
\hline & IL-6 & $20 \mathrm{ng} / \mathrm{mL}$ for $40 \mathrm{~min}$ & guinea-pig & adult ventricular myocytes & Aromolaran et al., 2018 \\
\hline \multirow[t]{5}{*}{ Hypoxia } & $\begin{array}{l}\text { Gases } \\
\text { concentration }\end{array}$ & $\begin{array}{l}95 \% \mathrm{~N}_{2}-5 \% \mathrm{CO}_{2} \text { (different } \\
\text { regimens of time) }\end{array}$ & rat & $\begin{array}{l}\text { neonatal ventricular } \\
\text { cardiomyocytes }\end{array}$ & Yamauchi-Takihara et al., 1995 \\
\hline & $\begin{array}{l}\text { Gases } \\
\text { concentration }\end{array}$ & not described & rat & $\begin{array}{l}\text { neonatal ventricular } \\
\text { cardiomyocytes }\end{array}$ & Wang et al., 2016 \\
\hline & $\begin{array}{l}\text { Gases } \\
\text { concentration } \\
\text { and culture } \\
\text { medium }\end{array}$ & $\begin{array}{l}\text { nitrogen equilibrated DMEM } \\
\text { and } 1 \% \mathrm{O}_{2} \text { and } 5 \% \mathrm{CO}_{2} \text { for } 2 \text {, } \\
4,6,8,10 \text {, and } 12 \mathrm{~h}\end{array}$ & mouse & neonatal cardiomyocytes & Shi et al., 2017 \\
\hline & $\begin{array}{l}\text { Gases } \\
\text { concentration }\end{array}$ & $\begin{array}{l}1 \% \mathrm{O}_{2} \text { (adjusted by } \mathrm{N}_{2} \\
\text { replacement in different } \\
\text { regimens of time) }\end{array}$ & human/chimpanzee & iPSC-CMs & Ward and Gilad, 2019 \\
\hline & $\begin{array}{l}\text { Gases } \\
\text { concentration }\end{array}$ & $\begin{array}{l}1 \% \mathrm{O}_{2} \text { (adjusted by } \mathrm{N}_{2} \\
\text { replacement) }\end{array}$ & human & iPSC-CMs & Plant et al., 2020 \\
\hline \multirow[t]{2}{*}{$\begin{array}{l}\text { Electrolyte imbalance } \\
\text { (hypokalemia) }\end{array}$} & $\begin{array}{l}\mathrm{K}^{+} \text {concentration } \\
\text { in the medium }\end{array}$ & $\begin{array}{l}5.33,4,3,2 \text { and } 1 \mathrm{mM} \text { of } \mathrm{K}^{+} \\
\text {(adjusted by adding } \mathrm{KCl} \text { into a } \\
\mathrm{K}^{+} \text {free medium) }\end{array}$ & human & iPSC-CMs & Kuusela et al., 2017 \\
\hline & $\begin{array}{l}\mathrm{K}^{+} \text {concentration } \\
\text { in buffer solution }\end{array}$ & $\begin{array}{l}\text { from } 5 \text { to } 2.7 \mathrm{mmol} / \mathrm{L} \text { rapidly } \\
\text { reduction of } \mathrm{K}^{+} \text {superfusion }\end{array}$ & rat & $\begin{array}{l}\text { atrial and ventricular adult } \\
\text { myocytes }\end{array}$ & Tazmini et al., 2020 \\
\hline Hyperthermia & $\begin{array}{l}\text { Temperature } \\
\text { increase }\end{array}$ & 36 vs. $40^{\circ} \mathrm{C}$ & human & iPSC-CMs & El-Battrawy et al., 2016 \\
\hline \multirow[t]{3}{*}{$\mathrm{HCM}$} & MYH7 & $\begin{array}{l}\text { missense mutation } \\
\text { (Arginine442Glycine) }\end{array}$ & human & iPSC-CMs & Han et al., 2014 \\
\hline & MYBPC3 & c.2373dupG mutation & human & iPSC-CMs & Birket et al., 2015 \\
\hline & MYBPC3 & heterozygous c. 1358-1359insC & human & iPSC-CMs & Prondzynski et al., 2017 \\
\hline \multirow[t]{2}{*}{ DCM } & $\begin{array}{l}\text { phospholamban } \\
\text { (PLN) }\end{array}$ & R14del mutation & human & iPSC-CMs & Stillitano et al., 2016 \\
\hline & LMNA gene & $\begin{array}{l}\text { R225X, Q354X, and T518fs } \\
\text { patient mutation }\end{array}$ & human & iPSC-CMs & Lee et al., 2017 \\
\hline
\end{tabular}

from drug treatments (Varshneya et al., 2020). These studies (Sutanto and Heijman, 2020; Varshneya et al., 2020) suggests that future work needs to address how pre-existing diseases and COVID-19 clinical presentation (e.g., hyperinflammation, fever, ion imbalance) may affect arrhythmia susceptibility.

The use of in silico models to simulate electrophysiological perturbations and to predict disease severity and treatment efficacy is a mature field of research (Lancaster and Sobie, 2016; Passini et al., 2017; Jæger et al., 2019a,b; Li et al., 2019; Gando et al., 2020). Dynamic models of cardiomyocyte's electrophysiology are particularly useful for simulating betweenpatient variability (Muszkiewicz et al., 2016), allowing the study of phenotypic minorities, such as high-risk COVID-19 patients (Varshneya et al., 2020). This variability among individuals is hard to replicate in other model types (e.g., in vivo, in vitro).
Further, in silico approaches can provide a quick illustration of how multiple factors in combinations (e.g., cytokine storm plus pre-existing diseases plus drug-treatments), can exacerbate positive or negative outcomes.

Over the past decades numerous in silico models that resemble electrophysiological properties of cardiomyocytes have been proposed based on experimental data from different species (Krogh-Madsen et al., 2016; Mayourian et al., 2018). These models can be used to highlight physio- and pathophysiological characteristics of ion channels and cellular compartments, as well as their intricate relationships, in order to gain a mechanistic understanding of a variety of illnesses and drug-treatments (Pandit et al., 2003; Sarkar and Sobie, 2011; Petkova-Kirova et al., 2012; Atkinson et al., 2016; Devenyi and Sobie, 2016; Das et al., 2017; Paci et al., 2018; Varshneya et al., 2018; 
Gong et al., 2020; Sutanto et al., 2020). However, only few models that mimic inflammation (Petkova-Kirova et al., 2012) and hyperthermia (Atkinson et al., 2016) can be found in the literature, posing barriers to the modeling of COVID-19 secondary effects on cardiomyocytes. Further, many of these models are based on animal experiments, limiting translation of their findings.

It is worth mentioning that most of the models previously cited are based on ordinary differential equations (ODEs) and describe the action potential and calcium transient of an isolated cardiomyocyte. Therefore, these models cannot assess how interactions among cardiomyocytes as well as with fibroblasts and other cell types contribute to the overall cardiac function. These shortcomings can be addressed by bi-(2D) and tridimensional (3D) models (e.g., fiber, tissue), where electrical coupling and the resultant tissue-level behavior can be simulated (Lines et al., 2002; Jæger et al., 2019a; Hwang et al., 2020). These models can be used to investigate mechanisms of cardiac arrhythmia, such as cardiac reentry that can be induced by Early After Depolarizations (EADs). Complex models are promising and can be particularly beneficial considering correlations with experimental data obtained from 3D hiPSC-CM models (e.g., field potential assessments by MEA in hiPSC-CM monolayers or 3D structures) (Kügler, 2020). However, these spatial models are more computationally expensive and are less frequently used than single-cell models (Jæger et al., 2019a). The most significant in silico models able to partially simulate COVID-19 effect in cardiomyocytes are listed in Table 2.

\section{DISCUSSION/PERSPECTIVE}

Despite the rapid dissemination of high-quality science during the COVID-19 pandemic, crucial gaps of knowledge remain open. Here, we (1) reviewed the most up to date protocols

TABLE 2 | In silico models to be used to mimic "COVID-19 cardiomyocytes."

\begin{tabular}{|c|c|c|c|c|c|}
\hline Outcome & Stimuli & Treatment/Simulation & Specie & Cell type & References \\
\hline $\begin{array}{l}\text { Drug-treatment } \\
\text { ( } \beta \text {-adrenergic signaling) }\end{array}$ & $\begin{array}{l}\text { healthy cells under } \\
\text { sympathetic stimulation }\end{array}$ & $\mathrm{CQ}, \mathrm{AZM}$ & dog & ventricular cardiomyocytes & $\begin{array}{l}\text { Sutanto and Heijman, } \\
2020\end{array}$ \\
\hline $\begin{array}{l}\text { Drug-treatment, heart } \\
\text { failure, gender }\end{array}$ & $\begin{array}{l}\text { healthy cells and heart } \\
\text { failure cells from male and } \\
\text { female }\end{array}$ & $\mathrm{CQ}, \mathrm{AZM}, \mathrm{LP}, \mathrm{RT}$ & human & $\begin{array}{l}\text { endocardial ventricular } \\
\text { myocytes }\end{array}$ & Varshneya et al., 2020 \\
\hline Drug-treatment & healthy cells & Several drugs & human & ventricular cardiomyocytes & $\begin{array}{l}\text { Lancaster and Sobie, } \\
2016\end{array}$ \\
\hline Drug-treatment & healthy cells & several drugs & human & ventricular cardiomyocytes & Passini et al., 2017 \\
\hline Drug-treatment & $\begin{array}{l}\text { healthy cells/dynamic } \\
\text { hERG submodels }\end{array}$ & several drugs & human & ventricular cardiomyocytes & Li et al., 2019 \\
\hline $\begin{array}{l}\text { Genetic disease (Q1475P } \\
\mathrm{Na}_{\vee} 1.5 \text { mutation) }\end{array}$ & $\begin{array}{l}\text { healthy cells modified by } \\
\text { Markov model for fast and } \\
\text { late } \mathrm{Na}^{+} \text {current }\end{array}$ & $\mathrm{Na}_{v} 1.5$ mutation & human & $\begin{array}{l}\text { endocardial ventricular } \\
\text { myocytes }\end{array}$ & Gando et al., 2020 \\
\hline $\begin{array}{l}\text { Comorbidity (diabetes } \\
\text { type-l) }\end{array}$ & $\begin{array}{l}\text { streptozotocin-induced, } \\
\text { type-I diabetes in rats }\end{array}$ & $\begin{array}{l}\text { baseline model vs. diabetes } \\
\text { model }\end{array}$ & rat & $\begin{array}{l}\text { right ventricle } \\
\text { cardiomyocytes }\end{array}$ & Pandit et al., 2003 \\
\hline Ion current changes & $75 \%$ block of $\mathrm{I}_{\mathrm{Kr}}$ & baseline vs. I $I_{\text {rr }}$ blocked cells & dog and human & ventricular cardiomyocytes & Sarkar and Sobie, 2011 \\
\hline $\begin{array}{l}\text { Arrhythmogenic } \\
\text { susceptibility }\end{array}$ & $\begin{array}{l}\text { changes in the } \\
\text { conductances of } I_{K r} \text { and } I_{K s}\end{array}$ & $\begin{array}{l}\text { baseline vs. } I_{K r} \text { and } I_{K s} \\
\text { modified cells }\end{array}$ & several & ventricular cardiomyocytes & Varshneya et al., 2018 \\
\hline $\begin{array}{l}\beta \text {-adrenergic } \\
\text { signaling/activity }\end{array}$ & $\begin{array}{l}\text { healthy cells under } \\
\text { sympathetic }\end{array}$ & $\begin{array}{l}\text { human model parametrization } \\
\text { for } \beta \text {-adrenergic system }\end{array}$ & human & $\begin{array}{l}\text { epicardial ventricular } \\
\text { cardiomyocytes }\end{array}$ & Gong et al., 2020 \\
\hline Inflammation/Hypertrophy & $\begin{array}{l}\text { TNF- } \alpha \text { overexpression in } \\
\text { the heart }\end{array}$ & $\begin{array}{l}\text { Parameterization using } \\
\text { cardiomyocytes isolated from } \\
\text { hearts overexpressing TNF- } \alpha\end{array}$ & mouse & $\begin{array}{l}\text { apical ventricular } \\
\text { cardiomyocytes }\end{array}$ & $\begin{array}{l}\text { Petkova-Kirova et al., } \\
2012\end{array}$ \\
\hline Hyperthermia (fever) & Fever & $\begin{array}{l}\text { baseline vs. adjusted model } \\
\text { for fever based on malaria }\end{array}$ & human & $\begin{array}{l}\text { atrial and ventricular } \\
\text { cardiomyocytes }\end{array}$ & Atkinson et al., 2016 \\
\hline $\begin{array}{l}\text { Drug-treatments, model } \\
\text { validation, ion current } \\
\text { changes }\end{array}$ & $\begin{array}{l}\text { healthy cells vs. } \\
\text { modifications: physiological } \\
\text { and cardiotoxic spectrum }\end{array}$ & $\begin{array}{l}\text { Tetrodotoxin, nifedipine, } \\
\text { 3R4S-Chromanol 293B, } \\
\text { E4031 }\end{array}$ & human & $\begin{array}{l}\text { Atrial and ventricular } \\
\text { hiPSC-CMs }\end{array}$ & Paci et al., 2013 \\
\hline $\begin{array}{l}\text { Ion imbalances, heart } \\
\text { failure, hiPSC-CM/adult } \\
\text { cardiomyocytes } \\
\text { predictions }\end{array}$ & $\begin{array}{l}\text { healthy cells vs. a variety of } \\
\text { conditions and species } \\
\text { cross predictions and } \\
\text { validations }\end{array}$ & $\begin{array}{l}\text { ion channel blocks, ion buffer } \\
\text { composition changes, pacing } \\
\text { rates, heart failure }\end{array}$ & $\begin{array}{l}\text { human, guinea pig, } \\
\text { rabbit }\end{array}$ & $\begin{array}{l}\text { iPSC-CMs (human) and } \\
\text { adult cardiomyocytes } \\
\text { (different species) }\end{array}$ & Gong and Sobie, 2018 \\
\hline $\begin{array}{l}\text { hiPSC-CM/adult cardiac } \\
\text { microtissues, } \\
\text { Drug-treatments }\end{array}$ & $\begin{array}{l}\text { healthy microtissues from } \\
\text { hiPSC-CMs }\end{array}$ & $\begin{array}{l}\text { Cisapride and verapamil } \\
\text { treatments (different doses) }\end{array}$ & human & $\begin{array}{l}\text { iPSC-CMs (human)/adult } \\
\text { myocytes }\end{array}$ & Tveito et al., 2018 \\
\hline $\begin{array}{l}\text { hiPSC-CM/adult cardiac } \\
\text { microtissues, } \\
\text { Drug-treatments }\end{array}$ & $\begin{array}{l}\text { healthy microtissues from } \\
\text { hiPSC-CMs }\end{array}$ & $\begin{array}{l}\text { Cisapride, verapamil, } \\
\text { lidocaine, nifedipine, } \\
\text { flecainide (many dose) }\end{array}$ & human & $\begin{array}{l}\text { iPSC-CMs (human)/adult } \\
\text { myocytes }\end{array}$ & Jæger et al., 2020 \\
\hline
\end{tabular}


used to study COVID-19 effects in cardiomyocytes, and (2) reviewed several in vitro and in silico models of inflammation, ischemia/hypoxia, hyperthermia, hypokalemia, and hypertrophy, with great relevance cardiovascular effects of COVID-19 that are not due to direct infection of cardiomyocytes by SARS-CoV-2.

In this scenario, hiPSC-CMs emerge as a promising platform for modeling COVID-19. However, these cells display limited maturation and biological heterogeneity, partly due to a lack of consensus protocols for their generation and characterization, negatively contributing to their clinical translation (Lundy et al., 2013; Robertson et al., 2013; Koivumäki et al., 2018; Gintant et al., 2019; Hoang et al., 2019; Ribeiro et al., 2019). Several strategies have been proposed to overcome hiPSC-CMs maturation obstacles. Nonetheless, most of them only result in limited improvement, especially in the case of $2 \mathrm{D}$ models (Talkhabi et al., 2016; Sun and Nunes, 2017). In parallel, 3D models such as cardiac spheroids (Polonchuk et al., 2017; Mattapally et al., 2018) and "engineered heart tissues" (EHTs) (Nunes et al., 2013; Stoehr et al., 2014) have shown promising results toward obtaining mature cells and a phenotype that more closely resembles adult tissue. However, the specialized expertise required for $3 \mathrm{D}$ technologies and the expense of these assays remains a challenge that limits the use of these approaches for research groups that require scalable or high throughput implementation (Zuppinger, 2019).

Additionally, in silico models of hiPSC-CMs' electrophysiology became a reality (Paci et al., 2013, 2018; Gong and Sobie, 2018; Tveito et al., 2018; Jæger et al., 2020), allowing the simulation of disease effects and drug toxicity (Gong and Sobie, 2018; Jæger et al., 2020). Similarly to the case of experimental models, there are peculiarities and limitations for modeling cardiomyocytes in silico (Gong et al., 2017). However, in silico models have the flexibility of being easily adapted to new experimental data, such as the ones obtained from hiPSC-CMs, allowing for more accurate quantitative predictions (Lei et al., 2017; Jæger et al., 2020; Paci et al., 2020). Furthermore, the most recent mechanistic models permit an improved translation of electrophysiological findings from hiPSC-CMs to human adult myocytes at both single-cell and tissue level (Gong and Sobie, 2018; Tveito et al., 2018). Overall, these strategies consider proportional changes in proteins expression throughout maturation without significant changes in the cell's function. Therefore, regression models, among other strategies can be used to parameterize ion current densities and correlate hiPSC-CM to adult cardiomyocyte models (Gong and Sobie, 2018; Tveito et al., 2018).

Currently, universal protocols for the generation and characterization of hiPSC-CMs are not available. Depending on their application, strengths and weaknesses exist for both 2D and 3D models (Zuppinger, 2019). Especially in the context of a pandemic, strengths, and weaknesses should be pondered to allow for fast and meaningful experimental research. The

\section{REFERENCES}

Akhmerov, A., and Marbán, E. (2020). COVID-19 and the heart. Circ. Res. 126, 1443-1455. doi: 10.1161/CIRCRESAHA.120.31 7055 best models of choice in this scenario are the ones that can generate accurate results but in a timely fashion. Independently of the model of choice, experiments need to be conducted in well-controlled environment, replicated for different cell lines, and always accompanied by negative controls (non-treated, healthy). Analogously, in silico models should be chosen to best match the experimental approach. The interpretation of results needs to be cautious, always considering the intrinsic limitations of each model.

Thus, the integration of experimental data obtained from hiPSC-CMs (single-cell, 2D, and 3D models) with appropriate in silico models that can quantitatively predict functional cardiac outcomes in adult cells is of paramount importance. hiPSCCMs from healthy donors or patients with pre-established comorbidities can be utilized to investigate in vitro the reaction of cardiomyocytes to several conditions precipitated by the systemic effects of SARS-CoV-2 infection. Many of these models were discussed in this mini review. The results obtained from experiments with hiPSC-CMs will provide valuable information that can be integrated into in silico models and used to predict disease progression and the effects of treatment.

In conclusion, we presented a perspective on how to combine in vitro and in silico approaches to generate humanbased platforms to study COVID-19 repercussions on the cardiomyocyte's function. The use of robust and precise models and their integration in mechanistic platforms may contribute substantially to understanding the impact of COVID-19 and COVID-19 drug treatments on the heart, constituting an additional source of guidance to help clinicians in the front line.

\section{AUTHOR CONTRIBUTIONS}

RD conceived the manuscript and wrote the initial draft. CC, AG, and ES helped to edit the manuscript. All authors contributed to the article and approved the submitted version.

\section{FUNDING}

Research on cardiomyocytes and drug-induced arrhythmias in Dr. Sobie's laboratory was funded by the National Heart, Lung, and Blood Institute projects U01 HL 136297 and R44HL139248.

\section{ACKNOWLEDGMENTS}

We thank Ananya Pavuluri, Itziar Irurzun Arana, Meera Varshneya, Taylor Pullinger, and Angelita Dona for the discussions during this time of pandemic, that were all very insightful for conceiving this manuscript.

Alhogbani, T. (2016). Acute myocarditis associated with novel Middle East respiratory syndrome coronavirus. Ann. Saudi Med. 36, 78-80. doi: 10.5144/ 0256-4947.2016.78

Aromolaran, A. S., Srivastava, U., Alí, A., Chahine, M., Lazaro, D., El-Sherif, N., et al. (2018). Interleukin-6 inhibition of hERG underlies risk for acquired long 
QT in cardiac and systemic inflammation. PLoS One 13:e0208321. doi: 10.1371/ journal.pone.0208321

Atkinson, L., Basharat, A., Benson, A. P., Colman, M. A., Holden, A. V., Kagugube, G. W., et al. (2016). Computational modelling of cardiac electrophysiological changes in malarial fever. Comput. Cardiol. (2010). 43, 1097-1100. doi: 10. 22489/cinc.2016.315-270

Bhatia, M., Zemans, R. L., and Jeyaseelan, S. (2012). Role of chemokines in the pathogenesis of acute lung injury. Am. J. Respir. Cell Mol. Biol. 46, 566-572. doi: 10.1165/rcmb.2011-0392TR

Bialek, S., Boundy, E., Bowen, V., Chow, N., Cohn, A., Dowling, N., et al. (2020). Severe outcomes among patients with coronavirus disease 2019 (COVID-19) United States, february 12-march 16, 2020. MMWR. Morb. Mortal. Wkly. Rep. 69, 343-346. doi: 10.15585/mmwr.mm6912e2

Birket, M. J., Ribeiro, M. C., Kosmidis, G., Ward, D., Leitoguinho, A. R., van de Pol, V., et al. (2015). Contractile defect caused by mutation in MYBPC3 revealed under conditions optimized for human PSC-Cardiomyocyte function. Cell Rep. 13, 733-745. doi: 10.1016/j.celrep.2015.09.025

Bojkova, D., Wagner, J. U. G., Shumliakivska, M., Aslan, G. S., Saleem, U., Hansen, A., et al. (2020). SARS-CoV-2 infects and induces cytotoxic effects in human cardiomyocytes. Cardiovasc. Res. 116, 2207-2215. doi: 10.1093/cvr/cvaa267

Borg, T. K., Rubin, K., Carver, W., Samarel, A., and Terracio, L. (1996). The cell biology of the cardiac interstitium. Trends Cardiovasc. Med. 6, 65-70. doi: 10.1016/1050-1738(96)00005-9

Burrell, C., Reddy, S., Haywood, G., and Cunningham, R. (2007). Cardiac arrest associated with febrile illness due to U.K. acquired Cyclospora cayetanensis. J. Infect. 54, e13-e15. doi: 10.1016/j.jinf.2006.03.020

Carreño, J. E., Apablaza, F., Ocaranza, M. P., and Jalil, J. E. (2006). Cardiac hypertrophy: molecular and cellular events. Rev. Española Cardiol. (English Ed. 59, 473-486. doi: 10.1016/s1885-5857(06)60796-2

Chary, M. A., Barbuto, A. F., Izadmehr, S., Hayes, B. D., and Burns, M. M. (2020). COVID-19: therapeutics and their toxicities. J. Med. Toxicol. 16, 284-294. doi: 10.1007/s13181-020-00777-5

Chen, L., Li, X., Chen, M., Feng, Y., and Xiong, C. (2020). The ACE2 expression in human heart indicates new potential mechanism of heart injury among patients infected with SARS-CoV-2. Cardiovasc. Res. 116, 1097-1100. doi: 10.1093/cvr/ cvaa078

Ciliberto, G., and Cardone, L. (2020). Boosting the arsenal against COVID-19 through computational drug repurposing. Drug Discov. Today 25, 946-948. doi: 10.1016/j.drudis.2020.04.005

Clerkin, K. J., Fried, J. A., Raikhelkar, J., Sayer, G., Griffin, J. M., Masoumi, A., et al. (2020). COVID-19 and cardiovascular disease. Circulation 141, 1648-1655. doi: 10.1161/CIRCULATIONAHA.120.046941

Cohn, J. N., Ferrari, R., and Sharpe, N. (2000). Cardiac remodeling-concepts and clinical implications: a consensus paper from an international forum on cardiac remodeling. J. Am. Coll. Cardiol. 35, 569-582. doi: 10.1016/S0735-1097(99) 00630-0

Coperchini, F., Chiovato, L., Croce, L., Magri, F., and Rotondi, M. (2020). The cytokine storm in COVID-19: an overview of the involvement of the chemokine/chemokine-receptor system. Cytokine Growth Factor Rev. 53, 25 32. doi: 10.1016/j.cytogfr.2020.05.003

Das, P. N., Kumar, A., Bairagi, N., and Chatterjee, S. (2017). Restoring calcium homeostasis in diabetic cardiomyocytes: an investigation through mathematical modelling. Mol. Biosyst. 13, 2056-2068. doi: 10.1039/c7mb00264e

Devenyi, R. A., and Sobie, E. A. (2016). There and back again: Iterating between population-based modeling and experiments reveals surprising regulation of calcium transients in rat cardiac myocytes. J. Mol. Cell. Cardiol. 96, 38-48. doi: 10.1016/j.yjmcc.2015.07.016

Dolhnikoff, M., Ferreira Ferranti, J., de Almeida Monteiro, R. A., Duarte-Neto, A. N., Soares Gomes-Gouvêa, M., Viu Degaspare, N., et al. (2020). SARS-CoV-2 in cardiac tissue of a child with COVID-19-related multisystem inflammatory syndrome. Lancet Child Adolesc. Heal. 4, 790-794. doi: 10.1016/S2352-4642(20) 30257- 1

El Khoury, N., Mathieu, S., and Fiset, C. (2014). Interleukin-1 $\beta$ reduces L-type $\mathrm{Ca} 2+$ current through protein kinase $\mathrm{C} \in$ activation in mouse heart. J. Biol. Chem. 289, 21896-21908. doi: 10.1074/jbc.M114.549642

El-Battrawy, I., Lang, S., Zhao, Z., Akin, I., Yücel, G., Meister, S., et al. (2016). Hyperthermia influences the effects of sodium channel blocking drugs in human-induced pluripotent stem cell-derived cardiomyocytes. PLoS One 11:e0166143. doi: 10.1371/journal.pone.0166143

Fox, S. E., Akmatbekov, A., Harbert, J. L., Li, G., Quincy Brown, J., and Vander Heide, R. S. (2020a). Pulmonary and cardiac pathology in African American patients with COVID-19: an autopsy series from New Orleans. Lancet Respir. Med. 8, 681-686. doi: 10.1016/S2213-2600(20)30243-5

Fox, S. E., Li, G., Akmatbekov, A., Harbert, J. L., Lameira, F. S., Brown, J. Q., et al. (2020b). Unexpected features of cardiac pathology in COVID-19 infection. Circulation 142, 1123-1125. doi: 10.1161/circulationaha.120.049465

Gando, I., Campana, C., Tan, R. B., Cecchin, F., Sobie, E. A., and Coetzee, W. A. (2020). A distinct molecular mechanism by which phenytoin rescues a novel long QT 3 variant. J. Mol. Cell. Cardiol. 144, 1-11. doi: 10.1016/j.yjmcc.2020. 04.027

Gebhard, C., Regitz-Zagrosek, V., Neuhauser, H. K., Morgan, R., and Klein, S. L. (2020). Impact of sex and gender on COVID-19 outcomes in Europe. Biol. Sex Differ. 11:29. doi: 10.1186/s13293-020-00304-9

Gintant, G., Burridge, P., Gepstein, L., Harding, S., Herron, T., Hong, C., et al. (2019). Use of human induced pluripotent stem cell-derived cardiomyocytes in preclinical cancer drug cardiotoxicity testing: a scientific statement from the american heart association. Circ. Res. 125, e75-e92. doi: 10.1161/RES. 0000000000000291

Golestaneh, L., Neugarten, J., Fisher, M., Billett, H. H., Gil, M. R., Johns, T., et al. (2020). The association of race and COVID-19 mortality. EClinicalMedicine 25:100455. doi: 10.1016/j.eclinm.2020.100455

Gong, J. Q. X., Shim, J. V., Núñez-Acosta, E., and Sobie, E. A. (2017). I love it when a plan comes together: insight gained through convergence of competing mathematical models. J. Mol. Cell. Cardiol. 102, 31-33. doi: 10.1016/j.yjmcc. 2016.10.015

Gong, J. Q. X., and Sobie, E. A. (2018). Population-based mechanistic modeling allows for quantitative predictions of drug responses across cell types. npj Syst. Biol. Appl. 4:11. doi: 10.1038/s41540-018-0047-2

Gong, J. Q. X., Susilo, M. E., Sher, A., Musante, C. J., and Sobie, E. A. (2020). Quantitative analysis of variability in an integrated model of human ventricular electrophysiology and $\beta$-adrenergic signaling. J. Mol. Cell. Cardiol. 143, 96-106. doi: 10.1016/j.yjmcc.2020.04.009

Goyal, P., Choi, J. J., Pinheiro, L. C., Schenck, E. J., Chen, R., Jabri, A., et al. (2020). Clinical characteristics of Covid-19 in New York City. N. Engl. J. Med. 382, 2372-2374. doi: 10.1056/NEJMc2010419

Granéli, C., Hicks, R., Brolén, G., Synnergren, J., and Sartipy, P. (2019). Diabetic cardiomyopathy modelling using induced pluripotent stem cell derived cardiomyocytes: recent advances and emerging models. Stem Cell Rev. Reports 15, 13-22. doi: 10.1007/s12015-018-9858-1

Grasselli, G., Zangrillo, A., Zanella, A., Antonelli, M., Cabrini, L., Castelli, A., et al. (2020). Baseline characteristics and outcomes of 1591 patients infected with SARS-CoV-2 admitted to ICUs of the lombardy region, Italy. JAMA 323:1574. doi: 10.1001/jama.2020.5394

Guan, W., Ni, Z., Hu, Y., Liang, W., Ou, C., He, J., et al. (2020). Clinical characteristics of coronavirus disease 2019 in China. N. Engl. J. Med. 382, 1708-1720. doi: 10.1056/NEJMoa2002032

Han, L., Li, Y., Tchao, J., Kaplan, A. D., Lin, B., Li, Y., et al. (2014). Study familial hypertrophic cardiomyopathy using patient-specific induced pluripotent stem cells. Cardiovasc. Res. 104, 258-269. doi: 10.1093/cvr/cvu205

Hirota, H., Yoshida, K., Kishimotot, T., and Taga, T. (1995). Continuous activation of gpl30, a signal-transducing receptor component for interleukin 6-related cytokines, causes myocardial hypertrophy in mice (interleukin 6 receptor). Proc. Natl. Acad. Sci. U.S.A. 92, 4862-4866. doi: 10.1073/pnas.92.11.4862

Hoang, P., Jacquir, S., Lemus, S., and Ma, Z. (2019). Quantification of contractile dynamic complexities exhibited by human stem cell-derived cardiomyocytes using nonlinear dimensional analysis. Sci. Rep. 9:14714. doi: 10.1038/s41598019-51197-7

Hoes, M. F., Bomer, N., and van der Meer, P. (2019). Concise review: the current state of human in vitro cardiac disease modeling: a focus on gene editing and tissue engineering. Stem Cells Transl. Med. 8, 66-74. doi: 10.1002/sctm.18-0052

Hoffmann, M., Kleine-Weber, H., Schroeder, S., Krüger, N., Herrler, T., Erichsen, S., et al. (2020). SARS-CoV-2 cell entry depends on ACE2 and TMPRSS2 and is blocked by a clinically proven protease inhibitor. Cell 181, 271.e-280.e. doi: 10.1016/j.cell.2020.02.052 
Huang, C., Wang, Y., Li, X., Ren, L., Zhao, J., Hu, Y., et al. (2020). Clinical features of patients infected with 2019 novel coronavirus in Wuhan, China. Lancet 395, 497-506. doi: 10.1016/S0140-6736(20)30183-5

Huang, L., Zhao, P., Tang, D., Zhu, T., Han, R., Zhan, C., et al. (2020). Cardiac involvement in patients recovered from COVID-2019 identified using magnetic resonance imaging. JACC Cardiovasc. Imaging 13, 2330-2339. doi: 10.1016/j. jcmg.2020.05.004

Hwang, M., Lim, C.-H., Leem, C. H., and Shim, E. B. (2020). In silico models for evaluating proarrhythmic risk of drugs. APL Bioeng. 4:021502. doi: 10.1063/1. 5132618

Iannaccone, G., Scacciavillani, R., Del Buono, M. G., Camilli, M., Ronco, C., Lavie, C. J., et al. (2020). Weathering the cytokine storm in COVID-19: therapeutic implications. Cardiorenal. Med. 10, 277-287. doi: 10.1159/00050 9483

Iqbal Choudhary, M. I., and Shaikh, M. (2020). In silico identification of potential inhibitors of key SARS-CoV-2 3CL hydrolase (Mpro) via molecular docking, MMGBSA predictive binding energy calculations, and molecular dynamics simulation. PLoS One 15:e0235030. doi: 10.1371/journal.pone.0235030

Ivorra, B., Ferrández, M. R., Vela-Pérez, M., and Ramos, A. M. (2020). Mathematical modeling of the spread of the coronavirus disease 2019 (COVID19) taking into account the undetected infections. The case of China. Commun. Nonlinear Sci. Numer. Simul. 88:105303. doi: 10.1016/j.cnsns.2020.105303

Jæger, K. H., Charwat, V., Charrez, B., Finsberg, H., Maleckar, M. M., Wall, S., et al. (2020). Improved computational identification of drug response using optical measurements of human stem cell derived cardiomyocytes in microphysiological systems. Front. Pharmacol. 10:1648. doi: 10.3389/fphar. 2019.01648

Jæger, K. H., Edwards, A. G., McCulloch, A., and Tveito, A. (2019a). Properties of cardiac conduction in a cell-based computational model. PLoS Comput. Biol. 15:e1007042. doi: 10.1371/journal.pcbi.1007042

Jæger, K. H., Wall, S., and Tveito, A. (2019b). Detecting undetectables: can conductances of action potential models be changed without appreciable change in the transmembrane potential? Chaos 29:073102. doi: 10.1063/1. 5087629

Jimenez-Tellez, N., and Greenway, S. C. (2019). Cellular models for human cardiomyopathy: what is the best option? World J. Cardiol. 11, 221-235. doi: 10.4330/wjc.v11.i10.221

Keck, M., Flamant, M., Mougenot, N., Favier, S., Atassi, F., Barbier, C., et al. (2019). Cardiac inflammatory CD11b/c cells exert a protective role in hypertrophied cardiomyocyte by promoting TNFR 2 - and Orai3- dependent signaling. Sci. Rep. 9, 1-18. doi: 10.1038/s41598-019-42452-y

Koivumäki, J. T., Naumenko, N., Tuomainen, T., Takalo, J., Oksanen, M., Puttonen, K. A., et al. (2018). Structural immaturity of human iPSC-derived cardiomyocytes: in silico investigation of effects on function and disease modeling. Front. Physiol. 9:80. doi: 10.3389/fphys.2018.00080

Krogh-Madsen, T., Sobie, E. A., and Christini, D. J. (2016). Improving cardiomyocyte model fidelity and utility via dynamic electrophysiology protocols and optimization algorithms. J. Physiol. 594, 2525-2536. doi: 10.1113/ JP270618

Kügler, P. (2020). Modelling and simulation for preclinical cardiac safety assessment of drugs with human iPSC-derived cardiomyocytes. Jahresbericht der Dtsch. Math. 122, 209-257. doi: 10.1365/s13291-020-00218-w

Kuusela, J., Larsson, K., Shah, D., Prajapati, C., and Aalto-Setala, K. (2017). Low extracellular potassium prolongs repolarization and evokes early after depolarization in human induced pluripotent stem cell-derived cardiomyocytes. Biol. Open 6, 777-784. doi: 10.1242/bio.024216

Lancaster, M. C., and Sobie, E. (2016). Improved prediction of drug-induced torsades de pointes through simulations of dynamics and machine learning algorithms. Clin. Pharmacol. Ther. 100, 371-379. doi: 10.1002/cpt.367

Lax, S. F., Skok, K., Zechner, P., Kessler, H. H., Kaufmann, N., Koelblinger, C., et al. (2020). Pulmonary arterial thrombosis in COVID-19 with fatal outcome: results from a prospective, single-center, clinicopathologic case series. Ann. Intern. Med. 173, 350-361. doi: 10.7326/m20-2566

Lee, Y., Lau, Y., Cai, Z., Lai, W., Wong, L., Tse, H., et al. (2017). Modeling treatment response for lamin A/C related dilated cardiomyopathy in human induced pluripotent stem cells. J. Am. Heart Assoc. 6:e005677. doi: 10.1161/JAHA.117. 005677
Lei, C. L., Wang, K., Clerx, M., Johnstone, R. H., Hortigon-Vinagre, M. P., Zamora, V., et al. (2017). Tailoring mathematical models to stem-cell derived cardiomyocyte lines can improve predictions of drug-induced changes to their electrophysiology. Front. Physiol. 8:986. doi: 10.3389/fphys.2017.00986

Li, Z., Ridder, B. J., Han, X., Wu, W. W., Sheng, J., Tran, P. N., et al. (2019). Assessment of an In Silico mechanistic model for proarrhythmia risk prediction under the CiPA initiative. Clin. Pharmacol. Ther. 105, 466-475. doi: 10.1002/ cpt.1184

Lindner, D., Fitzek, A., Bräuninger, H., Aleshcheva, G., Edler, C., Meissner, K., et al. (2020). Association of cardiac infection with SARS-CoV-2 in confirmed COVID-19 autopsy cases. JAMA Cardiol. 5, 1281-1285. doi: 10.1001/ jamacardio.2020.3551

Lines, G. T., Buist, M. L., Grottum, P., Pullan, A. J., Sundnes, J., and Tveito, A. (2002). Mathematical models and numerical methods for the forward problem in cardiac electrophysiology. Comput. Vis. Sci. 5, 215-239. doi: 10.1007/s00791003-0101-4

Litviňuková, M., Talavera-López, C., Maatz, H., Reichart, D., Worth, C. L., Lindberg, E. L., et al. (2020). Cells of the adult human heart. Nature 588, 466-472. doi: 10.1038/s41586-020-2797-4

Long, C. S. (2001). The role of interleukin-1 in the failing heart. Heart Fail. Rev. 6, 81-94.

Lundy, S. D., Zhu, W.-Z., Regnier, M., and Laflamme, M. A. (2013). Structural and functional maturation of cardiomyocytes derived from human pluripotent stem cells. Stem Cells Dev. 22, 1991-2002. doi: 10.1089/scd.2012.0490

Madjid, M., Safavi-Naeini, P., Solomon, S. D., and Vardeny, O. (2020). Potential effects of coronaviruses on the cardiovascular system. JAMA Cardiol. 5:831. doi: 10.1001/jamacardio.2020.1286

Marchiano, S., Hsiang, T.-Y., Higashi, T., Kanna, A., Reinecke, H., Yang, X., et al. (2020). SARS-CoV-2 infects human pluripotent stem cellderived cardiomyocytes, impairing electrical and mechanical function. bioRxiv [Preprint]. doi: 10.1101/2020.08.30.274464

Mattapally, S., Zhu, W., Fast, V. G., Gao, L., Worley, C., Kannappan, R., et al. (2018). Spheroids of cardiomyocytes derived from human-induced pluripotent stem cells improve recovery from myocardial injury in mice. Am. J. Physiol. Hear. Circ. Physiol. 315, 327-339. doi: 10.1152/ajpheart.00688.2017.-The

Mayourian, J., Sobie, E. A., and Costa, K. D. (2018). An introduction to computational modeling of cardiac electrophysiology and arrhythmogenicity. Methods Mol. Biol. 1816, 17-35. doi: 10.1007/978-1-4939-8597-5_2

McTiernan, C. F., Lemster, B. H., Frye, C., Brooks, S., Combes, A., and Feldman, A. M. (1997). Interleukin-1 $\beta$ inhibits phospholamban gene expression in cultured cardiomyocytes. Circ. Res. 81, 493-503. doi: 10.1161/01.RES.81.4.493

Michaud, V., Dow, P., Al Rihani, S. B., Deodhar, M., Arwood, M., Cicali, B., et al. (2020). Risk of drug-induced long QT syndrome associated with the use of repurposed COVID-19 drugs: a systematic review. medRxiv [Preprint]. doi: 10.1101/2020.04.21.20066761

Muszkiewicz, A., Britton, O. J., Gemmell, P., Passini, E., Sánchez, C., Zhou, X., et al. (2016). Variability in cardiac electrophysiology: using experimentally-calibrated populations of models to move beyond the single virtual physiological human paradigm. Prog. Biophys. Mol. Biol. 120, 115-127. doi: 10.1016/j.pbiomolbio. 2015.12.002

Muthuramalingam, P., Jeyasri, R., Valliammai, A., Selvaraj, A., Karthika, C., Gowrishankar, S., et al. (2020). Global multi-omics and systems pharmacological strategy unravel the multi-targeted therapeutic potential of natural bioactive molecules against COVID-19: an in silico approach. Genomics 112, 4486-4504. doi: 10.1016/j.ygeno.2020.08.003

Nakamura, K., Fushimi, K., Kouchi, H., Mihara, K., Miyazaki, M., Ohe, T., et al. (1998). Inhibitory effects of antioxidants on neonatal rat cardiac myocyte hypertrophy induced by tumor necrosis factor- $\alpha$ and angiotensin II. Circulation 98, 794-799. doi: 10.1161/01.CIR.98.8.794

Nunes, S. S., Miklas, J. W., Liu, J., Aschar-Sobbi, R., Xiao, Y., Zhang, B., et al. (2013). Biowire: a platform for maturation of human pluripotent stem cell-derived cardiomyocytes. Nat. Methods 10, 781-787. doi: 10.1038/nmeth. 2524

Paci, M., Hyttinen, J., Aalto-Setälä, K., and Severi, S. (2013). Computational models of ventricular-and atrial-like human induced pluripotent stem cell derived cardiomyocytes. Ann. Biomed. Eng. 41, 2334-2348. doi: 10.1007/s10439-0130833-3 
Paci, M., Passini, E., Klimas, A., Severi, S., Hyttinen, J., Rodriguez, B., et al. (2020). All-optical electrophysiology refines populations of in silico human iPSC-CMs for drug evaluation. Biophys. J. 118, 2596-2611. doi: 10.1016/j.bpj.2020.03.018

Paci, M., Pölönen, R. P., Cori, D., Penttinen, K., Aalto-Setälä, K., Severi, S., et al. (2018). Automatic optimization of an in silico model of human iPSC derived cardiomyocytes recapitulating calcium handling abnormalities. Front. Physiol. 9:709. doi: 10.3389/fphys.2018.00709

Pandit, S. V., Giles, W. R., and Demir, S. S. (2003). A mathematical model of the electrophysiological alterations in rat ventricular myocytes in type-I diabetes. Biophys. J. 84, 832-841. doi: 10.1016/S0006-3495(03)74902-9

Pasquié, J. L., Sanders, P., Hocini, M., Hsu, L. F., Scavée, C., Jais, P., et al. (2004). Fever as a precipitant of idiopathic ventricular fibrillation in patients with normal hearts. J. Cardiovasc. Electrophysiol. 15, 1271-1276. doi: 10.1046/j.15408167.2004.04388.x

Passini, E., Britton, O. J., Lu, H. R., Rohrbacher, J., Hermans, A. N., Gallacher, D. J., et al. (2017). Human in silico drug trials demonstrate higher accuracy than animal models in predicting clinical pro-arrhythmic cardiotoxicity. Front. Physiol. 8:668. doi: 10.3389/fphys.2017.00668

Pérez-Bermejo, J. A., Kang, S., Rockwood, S. J., Simoneau, C. R., Joy, D. A., Ramadoss, G. N., et al. (2020). SARS-CoV-2 infection of human iPSC-derived cardiac cells predicts novel cytopathic features in hearts of COVID-19 patients. bioRxiv Prepr. Serv. Biol. doi: 10.1101/2020.08.25.265561

Peterson, L. (2020). COVID-19 and Flavonoids: In Silico Molecular Dynamics Docking to the Active Catalytic Site of SARS-CoV and SARS-CoV-2 Main Protease (May 12, 2020). doi: 10.2139/ssrn.3599426

Petkova-Kirova, P. S., London, B., Salama, G., Rasmusson, R. L., and Bondarenko, V. E. (2012). Mathematical modeling mechanisms of arrhythmias in transgenic mouse heart overexpressing TNF- $\alpha$. Am. J. Physiol. Circ. Physiol. 302, H934H952. doi: 10.1152/ajpheart.00493.2011

Pinto, A. R., Ilinykh, A., Ivey, M. J., Kuwabara, J. T., D’Antoni, M. L., Debuque, R., et al. (2016). Revisiting cardiac cellular composition. Circ. Res. 118, 400-409. doi: 10.1161/CIRCRESAHA.115.307778

Plant, L. D., Xiong, D., Romero, J., Dai, H., and Goldstein, S. A. N. (2020). Hypoxia produces pro-arrhythmic late sodium current in cardiac myocytes by SUMOylation of NaV1.5 Channels. Cell Rep. 30, 2225-2236.e4. doi: 10.1016/j. celrep.2020.01.025

Polonchuk, L., Chabria, M., Badi, L., Hoflack, J. C., Figtree, G., Davies, M. J., et al. (2017). Cardiac spheroids as promising in vitro models to study the human heart microenvironment. Sci. Rep. 7:7005. doi: 10.1038/s41598-017-06385-8

Prondzynski, M., Krämer, E., Laufer, S. D., Shibamiya, A., Pless, O., Flenner, F., et al. (2017). Evaluation of MYBPC3 trans-Splicing and gene replacement as therapeutic options in human iPSC-derived cardiomyocytes. Mol. Ther. Nucleic. Acids 7, 475-486. doi: 10.1016/j.omtn.2017.05.008

Ribeiro, A., Guth, B., Engwall, M., Eldridge, S., Foley, C. M., Guo, L., et al. (2019). Considerations for an in vitro, cell-based testing platform for detection of druginduced inotropic effects in early drug development. Part 2: designing and fabricating microsystems for assaying cardiac contractility with physiological relevance using human iPSC-cardiomyocytes. Front. Pharmacol. 10:934. doi: 10.3389/fphar.2019.00934

Robertson, C., Tran, D. D., and George, S. C. (2013). Concise review: maturation phases of human pluripotent stem cell-derived cardiomyocytes. Stem Cells 31, 829-837. doi: 10.1002/stem.1331

Ruan, Q., Yang, K., Wang, W., Jiang, L., and Song, J. (2020). Clinical predictors of mortality due to COVID-19 based on an analysis of data of 150 patients from Wuhan. China. Intensive Care Med. 46, 846-848. doi: 10.1007/s00134020-05991-x

Saleh, M., Gabriels, J., Chang, D., Soo Kim, B., Mansoor, A., Mahmood, E., et al. (2020). Effect of chloroquine, hydroxychloroquine, and azithromycin on the corrected QT interval in patients with SARS-CoV-2 infection. Circ. Arrhythmia Electrophysiol. 13, 496-504. doi: 10.1161/CIRCEP.120.008662

Sarkar, A. X., and Sobie, E. A. (2011). Quantification of repolarization reserve to understand interpatient variability in the response to proarrhythmic drugs: a computational analysis. Hear. Rhythm 8, 1749-1755. doi: 10.1016/j.hrthm.2011. 05.023

Saura, D., García-Alberola, A., Carrillo, P., Pascual, D., Martínez-Sánchez, J., and Valdés, M. (2002). Brugada-like electrocardiographic pattern induced by fever. PACE Pacing Clin. Electrophysiol. 25, 856-859. doi: 10.1046/j.1460-9592.2002. t01-1-00856.x
Scheiner, S., Ukaj, N., and Hellmich, C. (2020). Mathematical modeling of COVID19 fatality trends: Death kinetics law versus infection-to-death delay rule. Chaos Solitons Fractals 136:109891. doi: 10.1016/j.chaos.2020.109891

Sharma, A., Garcia, G., Wang, Y., Plummer, J. T., Morizono, K., Arumugaswami, V., et al. (2020). Human iPSC-derived cardiomyocytes are susceptible to SARSCoV-2 infection. Cell Reports Med. 1:100052. doi: 10.1016/j.xcrm.2020.100052

Sharma, G., Volgman, A. S., and Michos, E. D. (2020). Sex differences in mortality from COVID-19 pandemic. JACC Case Reports 2, 1407-1410. doi: 10.1016/j. jaccas.2020.04.027

Shen, Y. L., Shi, Y. Z., Chen, G. G., Wang, L. L., Zheng, M. Z., Jin, H. F., et al. (2018). TNF- $\alpha$ induces drp1-mediated mitochondrial fragmentation during inflammatory cardiomyocyte injury. Int. J. Mol. Med. 41, 2317-2327. doi: 10. 3892/ijmm.2018.3385

Shi, H., Zhang, X., He, Z., Wu, Z., Rao, L., and Li, Y. (2017). Metabolites of hypoxic cardiomyocytes induce the migration of cardiac fibroblasts. Cell. Physiol. Biochem. 41, 413-421. doi: 10.1159/000456531

Smeets, P. J. H., Teunissen, B. E. J., Planavila, A., De Vogel-Van Den Bosch, H., Willemsen, P. H. M., Van Der Vusse, G. J., et al. (2008). Inflammatory pathways are activated during cardiomyocyte hypertrophy and attenuated by peroxisome proliferator-activated receptors PPAR $\alpha$ and PPAR $\delta$. J. Biol. Chem. 283, 29109-29118. doi: 10.1074/jbc.M802143200

Smith, T., Bushek, J., Leclaire, A., and Prosser, T. (2020). COVID-19 Drug Therapy. Amsterdam: Elsevier.

Stillitano, F., Turnbull, I. C., Karakikes, I., Nonnenmacher, M., Backeris, P., Hulot, J. S., et al. (2016). Genomic correction of familial cardiomyopathy in human engineered cardiac tissues. Eur. Heart J. 37, 3282-3284. doi: 10.1093/eurheartj/ ehw307

Stoehr, A., Neuber, C., Baldauf, C., Vollert, I., Friedrich, F. W., Flenner, F., et al. (2014). Automated analysis of contractile force and $\mathrm{Ca} 2+$ transients in engineered heart tissue. Am. J. Physiol. Heart Circ. Physiol. 306, H1353-H1363. doi: 10.1152/ajpheart.00705.2013

Sun, X., and Nunes, S. S. (2017). Bioengineering approaches to mature human pluripotent stem cell-derived cardiomyocytes. Front. Cell Dev. Biol. 5:19. doi: 10.3389/fcell.2017.00019

Sutanto, H., Cluitmans, M. J. M., Dobrev, D., Volders, P. G. A., Bébarová, M., and Heijman, J. (2020). Acute effects of alcohol on cardiac electrophysiology and arrhythmogenesis: Insights from multiscale in silico analyses. J. Mol. Cell. Cardiol. 146, 69-83. doi: 10.1016/j.yjmcc.2020.07.007

Sutanto, H., and Heijman, J. (2020). Beta-adrenergic receptor stimulation limits the cellular proarrhythmic effects of chloroquine and azithromycin. [Preprint]. doi: 10.20944/preprints202007.0418.v1

Talkhabi, M., Aghdami, N., and Baharvand, H. (2016). Human cardiomyocyte generation from pluripotent stem cells: a state-of-art. Life Sci. 145, 98-113. doi: $10.1016 /$ j.lfs.2015.12.023

Tazmini, K., Frisk, M., Lewalle, A., Laasmaa, M., Morotti, S., Lipsett, D. B., et al. (2020). Hypokalemia promotes arrhythmia by distinct mechanisms in atrial and ventricular myocytes. Circ. Res. 126, 889-906. doi: 10.1161/CIRCRESAHA.119. 315641

Tveito, A., Jæger, K. H., Huebsch, N., Charrez, B., Edwards, A. G., Wall, S., et al. (2018). Inversion and computational maturation of drug response using human stem cell derived cardiomyocytes in microphysiological systems. Sci. Rep. 8, 1-14. doi: 10.1038/s41598-018-35858-7

Varga, Z., Flammer, A. J., Steiger, P., Haberecker, M., Andermatt, R., Zinkernagel, A. S., et al. (2020). Endothelial cell infection and endotheliitis in COVID-19. Lancet 395, 1417-1418. doi: 10.1016/S0140-6736(20)30937-5

Varshneya, M., Devenyi, R. A., and Sobie, E. A. (2018). Slow delayed rectifier current protects ventricular myocytes from arrhythmic dynamics across multiple species. Circ. Arrhythm. Electrophysiol. 11:e006558. doi: 10.1161/ CIRCEP.118.006558

Varshneya, M., Irurzun-Arana, I., Campana, C., Dariolli, R., Gutierrez, A., Pullinger, T. K., et al. (2020). Investigational treatments for COVID-19 may increase ventricular arrhythmia risk through drug interactions. CPT Pharmacometrics Syst. Pharmacol. doi: 10.1002/psp4. 12573

Wang, J.-H., Zhao, L., Pan, X., Chen, N.-N., Chen, J., Gong, Q.-L., et al. (2016). Hypoxia-stimulated cardiac fibroblast production of IL-6 promotes myocardial fibrosis via the TGF- $\beta 1$ signaling pathway. Lab. Investig. 96, 839-852. doi: 10.1038/labinvest.2016.65 
Ward, M. C., and Gilad, Y. (2019). A generally conserved response to hypoxia in iPSC-derived cardiomyocytes from humans and chimpanzees. Elife 8:e42374. doi: $10.7554 /$ eLife.42374

Weiss, J. N., Qu, Z., and Shivkumar, K. (2017). Electrophysiology of hypokalemia and hyperkalemia. Circ. Arrhythmia Electrophysiol. 10:675. doi: 10.1161/ CIRCEP.116.004667

WHO (2020). World Health Organization. Coronavirus disease (COVID19) outbreak. Geneva World Heal. Organ. c2020. Geneva: World Health Organization.

Wicik, Z., Eyileten, C., Jakubik, D., Simões, S. N., Martins, D. C., Pavão, R., et al. (2020). ACE2 interaction networks in COVID-19: a physiological framework for prediction of outcome in patients with cardiovascular risk factors. J. Clin. Med. 9:3743. doi: $10.3390 / \mathrm{jcm} 9113743$

Wu, Z., and McGoogan, J. M. (2020). Characteristics of and important lessons from the coronavirus disease 2019 (COVID-19) outbreak in China. JAMA 323:1239. doi: 10.1001/jama.2020.2648

Xu, Z., Shi, L., Wang, Y., Zhang, J., Huang, L., Zhang, C., et al. (2020). Pathological findings of COVID-19 associated with acute respiratory distress syndrome. Lancet Respir. Med. 8, 420-422. doi: 10.1016/S2213-2600(20)3 0076-X

Yadaw, A. S., Li, Y.-C., Bose, S., Iyengar, R., Bunyavanich, S., and Pandey, G. (2020). Clinical features of COVID-19 mortality: development and validation of a clinical prediction model. Lancet Digit. Heal. 2, e516-e525. doi: 10.1016/ S2589-7500(20)30217-X

Yamauchi-Takihara, K., Ihara, Y., Ogata, A., Yoshizaki, K., Azuma, J., and Kishimoto, T. (1995). Hypoxic stress induces cardiac myocytederived interleukin-6. Circulation 91, 1520-1524. doi: 10.1161/01.CIR.91.5. 1520

Yang, L., Han, Y., Nilsson-Payant, B. E., Gupta, V., Wang, P., Duan, X., et al. (2020). A human pluripotent stem cell-based platform to study SARS-CoV-2 tropism and model virus infection in human cells and organoids. Cell Stem Cell 27, 125-136.e7. doi: 10.1016/j.stem.2020.06.015

Yang, N., and Shen, H.-M. (2020). Targeting the endocytic pathway and autophagy process as a novel therapeutic strategy in COVID-19. Int. J. Biol. Sci. 16, 1724-1731. doi: 10.7150/ijbs. 45498
Yu, C. M., Wong, R. S. M., Wu, E. B., Kong, S. L., Wong, J., Yip, G. W. K., et al. (2006). Cardiovascular complications of severe acute respiratory syndrome. Postgrad. Med. J. 82, 140-144. doi: 10.1136/pgmj.2005.037515

Zeb, A., Alzahrani, E., Erturk, V. S., and Zaman, G. (2020). Mathematical model for coronavirus disease 2019 (COVID-19) containing isolation class. Biomed Res. Int. 2020:3452402. doi: 10.1155/2020/3452402

Zhang, Y., Xu, Q., Sun, Z., and Zhou, L. (2020). Current targeted therapeutics against COVID-19: Based on first-line experience in China. Pharmacol. Res. 157:104854. doi: 10.1016/j.phrs.2020.104854

Zheng, Y.-Y., Ma, Y.-T., Zhang, J.-Y., and Xie, X. (2020). COVID-19 and the cardiovascular system. Nat. Rev. Cardiol. 17, 259-260. doi: 10.1038/s41569020-0360-5

Zhou, F., Yu, T., Du, R., Fan, G., Liu, Y., Liu, Z., et al. (2020). Clinical course and risk factors for mortality of adult inpatients with COVID-19 in Wuhan, China: a retrospective cohort study. Lancet 395, 1054-1062. doi: 10.1016/ S0140-6736(20)30566-3

Zhou, P., and Pu, W. T. (2016). Recounting cardiac cellular composition. Circ. Res. 118, 368-370. doi: 10.1161/CIRCRESAHA.116.308139

Zhou, Y., Hou, Y., Shen, J., Huang, Y., Martin, W., and Cheng, F. (2020). Networkbased drug repurposing for novel coronavirus 2019-nCoV/SARS-CoV-2. Cell Discov. 6:14. doi: 10.1038/s41421-020-0153-3

Zuppinger, C. (2019). 3D cardiac cell culture: a critical review of current technologies and applications. Front. Cardiovasc. Med. 6:87. doi: 10.3389/fcrm. 2019.00087

Conflict of Interest: The authors declare that the research was conducted in the absence of any commercial or financial relationships that could be construed as a potential conflict of interest.

Copyright (c) 2021 Dariolli, Campana, Gutierrez and Sobie. This is an open-access article distributed under the terms of the Creative Commons Attribution License (CC BY). The use, distribution or reproduction in other forums is permitted, provided the original author(s) and the copyright owner(s) are credited and that the original publication in this journal is cited, in accordance with accepted academic practice. No use, distribution or reproduction is permitted which does not comply with these terms. 